\title{
The role of subjectivity category in understanding the comunity context and the transforming intervention
}

\section{O papel da categoria subjetividade na compreensão do contexto comunitário e da intervenção transformadora}

\author{
Roberta KAFROUNI'
}

\begin{abstract}
The following article has as an objective to reflect on the importance of the category subjectivity, in the theoretical and methodological point of view, for Community Psychology. The intervention in Community Psychology cannot miss the subjective dimension of reality while it is part of the psychological field. In this sense, Social-Historical Psychology, the materialistic historical dialectic method and the subjectivity theory offer important contributions for the analysis of reality and transforming community intervention. The category subjectivity presents an alternative to the idealistic and dualistic visions of subjectivity. Its main features are presented in the article. In conclusion, this project tries to demonstrate how the method and the category subjectivity can offer a theoretical frame to the practice in Community Psychology through the consideration of practical experiences with community groups.
\end{abstract}

Uniterms: Community psychology; Psychology, social; Subjectivity.

\section{Resumo}

O presente artigo tem por objetivo refletir sobre a importância da categoria subjetividade, do ponto de vista teórico e metodológico, para a psicologia comunitária. A intervenção em psicologia comunitária não pode perder a dimensão subjetiva da realidade, posto que se constitui área do conhecimento psicológico. Nesse sentido, a psicologia sócio-histórica, o método materialista histórico dialético, a psicologia histórico-cultural e a teoria da subjetividade oferecem importantes contribuições para a análise da realidade e a intervenção comunitária transformadora. A categoria subjetividade apresenta uma alternativa às visões idealistas e dualistas de subjetividade, e, no artigo, são apresentados seus principais aspectos. Por fim, procura-se demonstrar como a categoria subjetividade pode subsidiar a prática em psicologia comunitária por meio da discussão de experiências junto a grupos comunitários.

Unitermos: Psicologia comunitária; Psicologia social; Subjetividade.

The Latin American Community Psychology is part of a historical movement that revises the role of Psychology in an economic and political context of inequality and oppression common in the countries of the region (Lane, 1996). Front to conditions that generate suffering, in which most of the population fit, the

$\boldsymbol{\nabla \nabla v \nabla}$

1 Universidade Tuiuti do Paraná, Programa de Mestrado em Psicologia. R. Sydnei Rangel Santos, 238, Santo Inácio, 82010-330, Curitiba, PR, Brasil. E-mail: <rkbeta@hotmail.com>. 
psychology professionals realized their deep theoretical and methodological incapacity, due to knowledge importation, built from other realities, and could offer neither explanatory nor practical support to the problems they faced.

Aiming at offering theoretical and methodological knowledge, a wide effort was made in order to face the dilemmas that Latin America Psychology faced. The concrete conditions that made the lives of most of the population difficult, contributed to the production of suffering, which is emotion. As Sawaia (1999) states, suffering is a psychological category that requires Social Psychology attention, which means restoring the ethical-political dimension of the subject, through the change of the perspective related to the role of emotions, within the concept of subjectivity.

It is worth pointing out that the task of building a theoretical framework for Latin America Community Psychology has faced the challenge of constituting, afterwards, the discussions and practices that founded the area (Rocha \& Pinheiro, 2011). The initial theoreticalmethodological production of the field was marked by the influence of external propositions of Psychology once its individualistic approach was inadequate for analising the situation of Latin American countries that suffered with acute social issues. If, on the one hand, this feature allowed the dialogue with important contributions of the fields of Sociology, Education and Politics, on the other hand, it seems to have, at first, distanced from the subjectivity and the subject issues, losing its specificity as a field of psychological knowledge.

In the construction process of this theoretical methodological process, some aspects demanded clarification. One of those is the concept of community, term that conveys different meanings, many times contrasting. Again, Sawaia (1996) contributes with a genealogy of the term in social thought. The author states that throughout western history, the concept was elated or rejected in the debate regarding men and society, which clearly explained its political dimension and brought to light the clash between individualistic and collectivist values.

The semantic diversity of the concept of community reveals epistemological and ethical positioning, which makes its explanation an important

122 and still somewhat problematic issue in the community
Psychology field. Taking, for instance, the statement of Gois (2005, p.60): the community "is a historical - cultural and psychological concept, a social and psychological construction appears throughout time, through direct and daily psychosocial relationships of dwellers of a certain place". The quote shows that community, under the author's point of view, has an important objectification basis, and that the community object is a pre-existing reality in the Community Psychology field. However, for Guareschi (1996, p.97), "the community relationships that constitute a real community are egalitarian relationships that happen among people that have rights and duties. These relationships imply that everybody has a voice and a turn; everybody is recognized in their singularity, where differences are respected". Such observation raises the concept of community as an object under construction: it does not take reality, therefore, as having a circumscription prior to a community psychology field, but as an object that it produces.

The procedures of the community object building appear in other definitions, such as Ribeiro and Lara Junior's (2011, p.592), which identify the community "as a political moment and not as a concept that is relevant to any human group", a field of stress and incompleteness, mainly as result.

The different concepts of community reflect the views of the practice of Community Psychology. According to Sawaia, "community is the action and reflection guiding category, and its content is extremely sensitive to the social context in which it lies, for it is associated to the millennial debate on social and ethical exclusion of good living" (Sawaia, 1996, p.50).

Given this definition it is mandatory to explicit the Community Psychology practice directions: the first aspect to be emphasized is social change. This point is fundamental and identifying to the Latin American perspective. Another aspect pointed by Lane (1996), is the importance of the group as a condition to the knowledge of reality and reflection as well as to the joint action.

At this point of the exhibition one could ask about the Community Psychology specificity: what makes it different from the practices of other areas of knowledge focused on social change and joint action? The distinctive aspect of Community Psychology is exactly the psychological or subjective dimension of 
reality. Lane (1996) states: "when one attempts to recover subjectivity, it necessarily affects identity, category that leads to the knowledge of one's singularity expressed in affective, motivational terms through the relations with the others - in other words, in group life" (Lane, 1996, p.30).

Thus, social change has subjective dimensions explained and known not only by psychologists, but also by the people involved in the group and in the change process.

When the role of subjectivity on the transforming action is placed, the adoption of an idealistic perspective of the community and of the subject, as if an interior change were the path to real changes, reaffirming dichotomies between internal and external, subjective and objective, so common in psychology, is not proposed. A view of the role of subjectivity within the transforming action requires an option for a theoretical position that tries to overcome such dichotomies. Therefore, we consider that the historical - cultural psychology contributions of the subjectivity theory of Fernando González Rey and of the Socio Historical Psychology offer important theoretical contributions to Community Psychology, which may guide the action and reflection of the Community Psychologist. Despite epistemological and theoretical differences, the previously mentioned perspectives present possibilities for dialogues due to their references in common - historical and dialectical materialism and the theoretical productions of Vygotsky. Notwithstanding the interpretation differences in this common basis, the later theoretical perspectives are alternative valid developments, with no possibility to determine heirs at law for the theoretical traditions (the Marxist method and the Vygotsky theory).

\section{Marx and Vygotsky's contribution to the subjectivity theory}

Newman and Holzman (2002) point out that Vygotsky was a psychologist/ methodologist, once he refused to make a distinction between the content of psychology and its method - the "what it is" of the "how to do it". As a methodologist he adopted the Marxist method - the historical dialectic Marxism - and presented with it a Psychology that did not focus on the simple description of human behavior, but on its explanation, which could only be reached by considering Men an active, social and historical being. The human being is a process not a static object, as well as the concrete whole world. Therefore, it could only be apprehended in its movement, contradiction and contribution. In other words, it is not a psychology task to establish a human nature theory as a set of constitutive categories for they change. It is necessary to develop a human approach method that allows grasping. As a consequence, one can say that Vygotsky's Psychology has a series of worries regarding the method.

The Marxist method is, before any other consideration, a way to approach reality. A way that totally opposes to how reality has been analyzed within Philosophy, since the Greeks (Newman \& Holzman, 2002). The philosophical thought is based, traditionally, on assumptions - hypothetically true definitions, from which reasoning is developed. However, for historical, dialectic materialism, assumptions are not hypothetical, but real.

This method of consideration is not destituted of presuppositions. It comes from real assumptions and not for a moment does it abandon them. Its assumptions are men, not any isolation and fantastic fixity, but in their process of real development and under certain conditions (Marx \& Engles, 2009, p.32).

Even spiritual productions are, under this point of view, results of men's material lives. "It is not consciousness that determines life, it is life that determines consciousness" (Marx \& Engles, 2009, p.32).

Therefore, the adoption of a Marxist method in the study of psychology permeates the overcoming of the long debate over mind nature. It allows the rejection of a determinist and essentialist view of the psyche and the taking of a "new complex systemic dimension, dialogic and dialectical, defined as ontological space" (González Rey, 2003 p.75).

At focusing on consciousness in the text Consciousness as a behavior psychology issue (Vygotsky, 1925/1991), Vygotsky emphasizes the need of an investigation method that fits the human behavior study, pointing at the impossibility of the use of a method directly derived from the animal behavior study. Then, Vygotsky states that in order to cover the totality of behavior, it is necessary to introduce new components 
to the formula. That happens because human behavior does not have only biological inheritance as a source: one of the fundamental components for human development is the fact that it takes the experience of previous generations, what the author called historic experience.

Besides historic experience, Vygotsky included another vital factor of human development - social experience. All the amount of experience lived by other people and that participate in the formation of a person is part of this social experience, although one has not experienced it directly.

Finally, a third peculiar aspect of human behavior is that it does not characterize through a passive adaptation to the environment, as it happens with animals. On the contrary, men actively adapt the environment to themselves. Referring to Marx, Vygotsky points out that men anticipate the result of their activity before performing it, which he called the duplication of experience at work.

These three factors - historic experience, social experience and doubled experience - are the fundaments of the explanation of cultural behavior, proposed by Vygotsky.

\section{The subject and subjectivity categories}

Considering the factors previously described, Vygotsky also contributed to the explanation of a person's development. In the text History of superior psychological functions development (1931/2000), the author indicates that human behavior, in particular, results from the transformation of lower psychological functions, those determined by biological inheritance, into higher psychological functions, formed by the mediation of signs. The basic transformation mechanism of the lower psychological functions into higher is the internalization process. This process has three basic features: an external activity (social) turns into an internal activity, this previous interpersonal activity becomes intrapersonal, and finally, due to the displacement, the very activity structure undergoes changes. The social behavior forms are assimilated and transferred to a person; in other words, the relationships among higher psychological functions were, previously,

124 relationships among men.
However, the internalization process is not a simple external into internal transference. Vygotsky shows that the development of a person entails the creation of the unique. The opening for the consideration of the psyche, though, as having the power of generating the unique, will only appear more clearly in the work of the author in his text Thought and Language (1934/1993).

In the first chapter of this text, Vygotsky, when elaborating on unit of analysis of the relationship between thought and language, already announced that individual experience is not, strictly speaking, transmitted, and that there is the need to generalize, given by the meanig of the word. Thus, communication can occur and it is possible to assume a psychological level that cannot be reduced to social.

One peculiarity of internal language is that a word carries more sense than in external language, that is, there is an enormous semantic content enclosed in the word. Vygotsky concludes, therefore, that the merging of various semantic contents in a single word supposes, in each case, the formation of an individual sense, untranslatable. It is demonstrated that the role of the subject in language, thus, without the inclusion of the notion of subject, it is not possible to understand the emergence of the internal language.

González Rey (2004) highlights that the category sense, designating a qualitatively different level of psychic phenomena that is not reducible to language, only appears in his text Thought and Language (1934/1993) and still, only in the last chapter (González Rey, 2011). The author points out that there are different moments in the works of Vygotsky, in which his theoretical production is characterized by discontinuities produced in a political and ideological context that privileged theoretical visions that were more consistent with this context. The result is that we can find in the work of Vygotsky, both a perspective of the psyche as reflection of a mechanically internalized reality (represented in the category conscience), as well as a conception of psyche as a production of singular senses and with its own ontology (represented in the category sense). The character of the psyche system, nevertheless, has always been present in the works of Vygotsky, although the system representation has varied throughout his work (González Rey, 2005). 
Vygotsky places the sense of the word inserted in speech, which is a moment of the subject. Thus, "the sense is an organization of psychological aspects that emerge in consciousness" (González Rey, 2004 p.49).

Sense is, therefore, an essential part of the process of subjectivation, responsible for defining the psychological experiences of the subject. It is also an element of articulation between what is historical and present in the configuration of the psyche. Therefore, "the category sense, as in the construct of Vygotsky, represents a constituting unit of subjectivity, capable of expressing complex processes of subjectivation in what it has of dynamic, irregular and contradictory" (González Rey, 2004, p.51). Consequently, in although the category subjectivity does not belong to the theoretical body of the construct of Vygotsky, its theoretical contributions allow the elaboration of a possible deployment of his work, which has been done by Fernando González Rey.

One of the advantages of the theory of subjectivity, as proposed by González Rey (2003), is that it takes the fundamental need to be articulated in relation to the notion of subject. A concrete subject that may not be separated from the psychological processes that Psychology tries to understand. Thus, one cannot speak, for example, about learning processes without considering the subject of the process. Subjectivity, therefore, can only be studied in concrete subjects. It is clear here the influence of dialectical and historical materialistic method, as stated by González Rey (2004, p.152): "my work has a strong Marxist influence in the sense of defending an ontological definition of subjectivity that articulates with all the aspects of people's lives".

The notion of subject has two distinct and necessary senses - the place of production of subjectivity and the capacity to become a subject - as it understands that individuals become subjects from the capacity of producing new subjective senses before the challenges of life.

The category subjectivity is complex and resists tight conceptualizations. It articulates simpler categories and admits dialogue with contributions from other areas of Social Psychology. In general, subjectivity is the system of senses and subjective senses, organized and articulated dynamically, which are expressed in various forms of activity and social spaces in which the subject operates. Individual subjectivity is a differentiated expression that is combined with unique subjective senses developed in the history of individual (González Rey, 2003). The category subjective sense is used by González Rey to emphasize the symbolic-affective unit that constitutes psychological productions.

The category of subjectivity has a processual character and is in constant movement. It is possible to know, however, the forms of organization of the senses, which are the subjective configurations. They integrate different elements of sense coming from different areas of the subject's life and have some relative stability (González Rey, 2003). Thus, we can know how to organize the various elements of sense that are produced by a given subject facing an activity. These elements of sense are not only related to the activity but update several other senses produced in other areas of life. For example, work can lead to senses related to a particular person's sense of gender, social status, family status and race, which shapes the subjective sense of work for this person.

The category subjective configuration allows the understanding that the social is not imposed in a mechanical way to the constitution of subjectivity, but it certainly is a constituent element of it. As the shared social spaces also participate in the formation of subjective senses, the social subjectivity category allows the understanding of ways of constituting subjective senses, both at the individual and social levels, as it refers to processes of sense triggered by social instances (González Rey, 2003). Thus, the study of individual subjects provides access to information about the social.

When addressing subjectivity, one can never understand it completely, since it is constantly changing. What can we learn are moments of subjectivity, individual and social, often related to specific social spaces, which generally concerns community psychology. We considered important for the study of subjectivity, thus, the categories subjective dimension of reality and subjective dimension of social phenomena, developed by the researchers from the Catholic University of São Paulo - Universidade Católica de São Paulo (Ana Bock, Odair Furtado, Wanda Aguiar, Maria da Graça Marquina M. Gonçalves). Bock and Gonçalves (2009, p.143) define subjective dimension of reality: "individual and collective constructions, that meet each other in a process of mutual constitution and that result in certain products that can be recognized as subjective". 
The category subjective dimension of social phenomena does not differ from the previous category, but emphasizes the possibility of social understanding. Bock and Gonçalves (2009, p.144) add that:"This means looking at social phenomena for the presence of a human being who is a subject, with processual, historical and complex subjectivity empasizing the dialectical unity between the individual and society". The authors also highlight the points of contact with the categories social subjectivity and Individual subjectivity proposed by González Rey, but emphasize that the categories proposed by them are directed to the object of social psychology, which is characterized as social phenomena. Interestingly, the authors do not draw a line between social-historical psychology and cultural-historical psychology, treating them as interchangeable terms: positioning to which we are favorable.

The category subjectivity is a complex one, which integrates and articulates different simpler categories and allows approaching the relationship between individuals and society in a non-dichotomous manner, and highlights the psychological dimension - or subjective - of this relationship (Gonçalves, 2003). Another positive aspect of the category subjectivity is that it reveals the concrete character of the psyche, objectively constituted by social reality and has as an objective social reality through concrete action.

\section{The subjectivity category and the understanding of the community context and transformation action}

However, what is the importance of the category subjectivity for the understanding of the communit context and the transformation action? Here, it becomes important to analyze a few cases experienced in practical work with groups in the internships of Community Psychology that we have developed over the past nine years. In this period, we have worked with groups of former prisoners and income generation groups. In work we developed together with a Non-Governmental Organization (NGO), the aim of the institution was to stimulate income-generating activities among the people living in communities with limited resources. The institution offered training to residents so that they 126 knew how to organize their work, plan expenses, and maintain equipment. In some instances, it offered credit and product development that could be made by the groups. The goal was to stimulate the development of cooperatives. The institution's complaint, however, is that the groups were not "motivated" or did not even get to constitute a group.

In socio-historical perspective (or culturalhistorical), motivation is not an intrinsic process to individuals. It is also not intrinsic to the task. Motivation is configured subjectively, which involves the needs subjectively constituted and the senses produced in a particular activity. Instead of offering our psychological services to support the stimulus to an alleged intrinsic capacity, we initially undertook to approach people in the community to listen to them and try to understand what was being described by the NGO as lack of motivation what could mean. The first issue that we came across was the need to understand the sense of the terms "cooperative" and "entrepreneurship", as well as the activity itself, represented to NGOs and community.

The proposal of cooperative relationship implies another relationship between capital and labor: it is not organized in the same way as employment. The relationships among the participants of cooperatives imply a breakdown of traditional hierarchy among workers, who now have greater control over the production process and its outcome.

The aim of the NGO was to stimulate not only cooperativeness, but the initiative of community members to create cooperative ventures, which involved identifying people with "leadership profile" that could organize groups of workers in the community.

The analyzes showed that the income generating groups qualified as demotivated by the NGO at that time were not able to take responsibility upon themselves as subjects of the processes that were expected from them. The strategy itself for seeking leaders would eventually prevent this from happening, because it institutionalized and crystallized the senses produced by a single person who imposed these senses on the rest of the group.

By listening to members of groups already established or in the process of constitution, however, one realizes that the organization in cooperatives met a 
number of constituent senses of the subjective dimension of work for the community residents. One must consider the social structure in which we are born and develop ourselves, where the submission to hierarchy is present in all social spaces (family, school, work organizations etc.). Such hierarchy is based on the division of existing classes in capitalist society. These are concrete aspects of reality that trigger processes of sense, which foster certain social subjectivity.

Another experiment that is experienced in stages is the work with groups of former prisoners. We worked closely with a government agency responsible for monitoring and supporting them. We have established discussion groups involving former prisioners with a court order for psychological counseling. In the groups, we could see that the exit from prison life and life in freedom again had a number of issues with which the former prisioners were faced and that needed to be identified and reflected upon, such as: relationships with their families, relations with the world of work, the sense of citizenship. We understand these issues as elements of sense that are organized into subjective configurations and mark the production of new senses given the new demands that life outside prison imposes on these people.

Once again, we realize that they were faced with concrete issues, such as unemployment, lack of resources and legal requirements. It was necessary, however, to reflect on the subjective senses produced by them given the new reality. Often former prisioners saw no other way out of the impasses of the everyday life return to criminal life. Such an alternative was imposed not only by the real difficulty in getting a job that would guarantee minimum conditions of survival, but also the ethical and political suffering experienced in finding a job legally acceptable. They suffered prejudice, and were often summarily dismissed as soon they informed that they had been convicted and imprisioned. They reported feeling like a "Walking Criminal Record", and the abuse suffered during police confrontation, to whom they were "eternal suspects". Many times, the return to the criminal path was paradoxically the only way they visualized to guard against their dignity. Since they could not be respected as citizens, they could at least be feared. Facing a shared social reality, however, subjective senses emerged from unique configurations that determined particular interpretations. This did not prevent, however, the presence of elements of shared subjective sense, which were, nevertheless, felt as personal.

Another question raised was the subjective dimension of citizenship. Recognizing one's rights to have rights was never effective for many former prisioners. However, because they had been sentenced to prision, many simply assumed they had no rights whatsoever, only obligations, which, often times, was assured by the professionals of the inspection institution responsible for them. The idea that they did not even have the right to complain, as they were still in debt with society, was common. This resulted in making it inviable for them to persue certain rights and support that were available to them exactly because they were former prisioners.

In order to understand what was happening with these groups, it was necessary to consider the concrete conditions that determined the subjective dimension of their reality. It was a necessity both for understanding as well as for transformative intervention.

Considering that, how can we intervene? Certainly the intervention in community psychology would not be driven to "training" or qualification courses of group members. The option was to provide the space for the production of sense before the aspects that constitute the subjective dimension of reality.

As previously mentioned, it has long been recognized that working with groups is an important tool in community psychology. In this sense, Lane (2001) makes important theoretical and methodological contributions. First, she claims that the group is not a static entity composed of constant elements that can be seen in any other group. It should be considered in its historically determined process. Furthermore, the relationship between the individual and the group is not dichotomous. The group is "a necessary condition to learn the social causes that act upon the individual, as well as its action as a historical subject, assuming that any society transformation action can only occur when individuals come together as a group" (Lane, 2001, p.78).

Lane $(2001$, p.96) proposed three categories for the analysis of the group process. The first was the 
production. "The group process is characterized as a productive activity". The second category is domination, ie, the analysis should include the infrastructural conditions that reproduce the relations of domination and how they reflect in the group. The last category is the group-subject, that is, Lane $(2001$, p.97) says that "a group is only a group when it is to produce something, to evolve and transform relations among members of the group". In the analysis process, the author shows that, in her remarks, as the contradictions are revealed, the group tended to crumble: this is an important criterion for analyzing the group process.

An important direction for work in community psychology is the rescue, by individuals and groups, of their status as subjects. This subject represents a moment of tension that can cause transformation, since the subject is in confrontation with what is established, both at the social as well as individual level. When the subject is capable of producing new senses before subjective activity, he represents the possibility of both changing itself and changing the social space in which he participates (González Rey, 2004). "True collectivism, efficient group work, can only be achieved through rich individualities, involved in all the richness of its expression with the teamwork" (González Rey, 2004, p.155).

Another important aspect is that a vision of subjectivity compromised with the emergence of true subjects implies that psychologists accept being destituted from their hierarchically superior status due to their knowledge. It implies accepting that psychologists cannot predict the production of senses and may not be able to drive the process. As a consequence, it breaks with Manichean views expressed in dichotomies such as alienated-aware, oppressoroppressed, which express fixed menaings about the community and its subjects. This way, it is possible to escape authoritarian positions frequently defended by those who, in the name of the combat against authoritarism, preach the dictatorship of a collective group condemned to a version of facts labeled as "power relations awareness". According to Rocha and Pinheiro (2011, p.494), "the ways of reading are not limited to the production of subjectivity based on a model of critical conscience". Thus, we rescue the political space understood as space for dialogue, for acknowledging difference, for the right to difference. This view, in various ways, we share with the authors (Rocha \& Pinheiro, 2011, p.494): "In the dialogue we want, what we seek is the exploration of conflict and of the dissent raised in the meeting of heterogeneous subjects".

The group work is often slow and faces institutional, financial and personal barriers. We can also perceive, however changes in the groups and in the subjects. In relation to the groups attended by the NGO, the development of discussions about work could be noticed, initially nonexistent, clearly outlining the relationship within the group and the development of self-expression and listening on the part of some members. In the case of groups of former prisoners, it could be noticed in some groups, the development of relationships of mutual aid among them. The search for the resources available to them and secured by law.

This allows us to identify some aspects needed for transformative community intervention, such as:

- The work in community psychology should put emphasis on the subjective dimension of reality, which is the specificity of psychologists.

- For a transformative intervention, a theoretical perspective that considers subjectivity as something concrete is necessary.

- The method is important to approach reality and for intervention and does not mean adopting a technique. Techniques that do not take into account the epistemological specificity in community psychology do not provide transformation, but constitute instruments of domination, of the imposition of a particular ideological and idealistic position.

The aspects mentioned here are important for making interventions committed with the ethical and aesthetic dimensions of the community contexts (Zanella \& Molon, 2007), which are not only the application of training techniques or qualification courses that may eventually be constituted of instruments for domination of those who, supposedly, we seek to free. The interventions need to have an ethical sense, since our practices have an impact on the subjective constitution of those to whom we provide the services.

\section{References}

Bock, A. M. B., \& Gonçalves, M. G. M. (2009). A dimensão subjetiva dos fenômenos sociais. In A. M. B. Bock \& M. G. M. Gonçalves (Orgs.), A dimensão subjetiva da realidade: uma leitura sócio-histórica. São Paulo: Cortez. 
Góis, C. W. L. (2005). Psicologia comunitária: atividade e consciência. Fortaleza: Publicações Instituto Paulo Freire de Estudos Psicossociais.

Gonçalves, M. G. M. (2003). Psicologia sócio-histórica e políticas públicas: a dimensão subjetiva de fenômenos sociais (Tese de doutorado não-publicada). Pontifícia Universidade Católica de São Paulo.

González Rey, F. L. (2003). Sujeito e subjetividade. São Paulo: Pioneira Thompsom Learning.

González Rey, F. L. (2004). O social na psicologia e a psicologia social: a emergência do sujeito. Petrópolis: Vozes.

González Rey, F. L. (2005). O valor heurístico da subjetividade na investigação psicológica. In F. L. González Rey. Subjetividade, complexidade e pesquisa em psicologia. São Paulo: Pioneira Thompsom Learning.

González Rey, F. L. (2011). El pensamiento de Vigotsky: contradicciones, desdoblamientos y desarrollo. México: Trillas.

Guareschi, P. (1996). Relações comunitárias: relações de dominação. In R. H. F. C. Campo (Org.), Psicologia social comunitária: da solidariedade à autonomia. Petrópolis: Vozes.

Lane, S. T. M. (1996). Histórico e fundamentos da psicologia comunitária no Brasil. In R. H. F. Campos. Psicologia social comunitária: da solidariedade à autonomia. Petrópolis: Vozes.

Lane, S. T. M. (2001). O processo grupal. In S. T. M. Lane \& W. Kodo (Orgs.), Psicologia social: o homem em movimento. São Paulo: Brasiliense.

Marx, K., \& Engels, F. (2009). A ideologia alemã. São Paulo: Expressão Popular.

Newman, F., \& Holzman, L. (2002). Lev Vygotsky: cientista e revolucionário. São Paulo: Loyola.
Ribeiro, C. T., \& Lara Junior, N. (2011). Comunidades e o campo da política. Fractal: Revista de Psicologia, 23(3), 579-594.

Rocha, T. G., \& Pinheiro, F. P. H. A. (2011). Políticas cognitivas da psicologia comunitária: a meio caminho entre a recognição e a invenção. Psicologia \& Sociedade, 23(3): 486-495.

Sawaia, B. B. (1996). Comunidade: a apropriação científica de um conceito tão antigo quanto a humanidade. In R. H. F. Campos (Org.), Psicologia social comunitária: da solidariedade à autonomia. Petrópolis: Vozes.

Sawaia, B. B. (1999). O sofrimento ético-político como categoria de análise da dialética exclusão/inclusão. In B. B. Sawaia. As artimanhas da exclusão: análise psicossocial e ética da desigualdade social. Petrópolis: Vozes.

Vygotsky, L. S. (1991). La conciencia como problema de la psicología del comportamiento. In L. S. Vygotsky. Obras escogidas (Tomo 1). Madrid: Centro de Publicaciones del M.E.C. (Originalmente publicado en 1925).

Vygotsky, L. S. (1993). Pensamento e linguagem. São Paulo: Martins Fontes. (Originalmente publicado em 1934).

Vygotsky, L. S. (2000). História el desarollo de lãs funciones psíquicas superiores. In L. S. Vygotsky. Obras Escogidas (Tomo 3). Madrid: Visor Dis. (Originalmente publicado en 1931).

Zanella, A. V., \& Molon, S. I. (2007). Psicologia [em] contextos de escolarização formal: das práticas de dominação à [re] invenção da vida. Revista Contrapontos, 7(2), 255-268.

Received on: 6/10/2011

Final version on: $31 / 5 / 2012$

Approved on: 22/6/2012 
